\title{
Parasitic Infestation in Patients Undergoing Appendectomy: Retrospective Analysis of 7,344 Cases
}

\section{Apendektomi Uygulanan Hastalarda Parazitik İstila: 7.344 Olgunun Retrospektif Analizi}

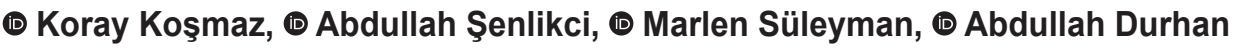 \\ Ankara Training and Research Hospital, Clinic of General Surgery, Ankara, Turkey
}

\section{IIIIIIII| ABSTRACT}

Aim: To evaluate the incidence, type and relationship with inflammation of parasitic infestation in patients undergoing appendectomy based on histopathological data.

Method: Retrospective examination was made of 7,344 appendectomy specimens. Parasitic infestation cases were evaluated in respect of age, gender, type of parasite and its relationship with inflammation.

Results: Evidence was found as to the presence of parasites was in $24(0.32 \%)$ of the appendectomy materials examined. Enterobius vermicularis was observed in 22 and Ascaris lumbricoides in 2 of the cases. The patients with parisitic infestation comprised 12 (50\%) males and 12 (50\%) females with a mean age of 36.5 years (range: 12-74 years). Inflammation was observed in 8 (33.3\%) patients and not observed in 16 (66.7\%) patients.

Conclusion: Acute appendicitis may be caused by parasites. Negative appendectomy rates were higher in patients with parasite in appendix lumen. However, it remains controversial whether every parasite infestation causes an appendicitis inflammatory response.

Keywords: Acute appendicitis, Enterobius vermicularis, parasite

\section{|l||l||l|| ÖZ}

Amaç: Apendektomi geçiren hastalarda parazitik enfestasyon insidansını, türünü ve enflamasyonla ilişkisini histopatolojik verilere dayanarak değerlendirmek.

Yöntem: 7.344 apendektomi örneğinin retrospektif incelemesi yapıldı. Parazitik enfestasyon olguları yaş, cinsiyet, parazit tipi ve enflamasyonla ilişkisi açısından değerlendirildi.

Bulgular: İncelenen apendektomi materyallerinin 24'ünde (\%0,32) parazit varlığına dair kanıt bulundu. Olguların 22'sinde Enterobius vermicularis ve 2'sinde Ascaris lumbricoides görüldü. Parazit istilası olan hastalar 12 (\%50) erkek ve 12 (\%50) kadındı ve yaş ortalaması 36,5 yıl (aralık: 12-74 yaş) idi. Sekiz $(\% 33,3)$ hastada enflamasyon görülürken, 16’sında $(\% 66,7)$ enflamasyon görülmedi.

Sonuç: Akut apandisit parazitlerden kaynaklanabilir. Apendiks lümeninde parazit bulunan hastalarda negatif apendektomi oranları daha yüksekti. Bununla birlikte, her parazit istilasının apandisit iltihabına neden olup olmadığı tartışmalıdır.

Anahtar Kelimeler: Akut apandisit, Enterobius vermicularis, parazit

\section{Introduction}

The appendix vermiformis (AV) is a narrow, blind-ended tubular organ connected to the cecum. Inflammation of the $\mathrm{AV}$ is known as acute appendicitis, and this is one of the most common inflammatory diseases of the gastrointestinal tract. A decrease in blood flow caused by obstruction in the appendiceal lumen, mucosal ischaemic damage and development of bacterial infection has influenced the pathogenesis of acute appendicitis. Acute inflammation is not observed in approximately $20 \%$ of patients undergoing appendectomy. ${ }^{1}$

Lymphoid hyperplasia, faecalites, fruit and vegetable seeds, barium enemas and tumours are the main components of the

Address for Correspondence/Yazışma Adresi: Abdullah Şenlikçi, MD, 
aetiology of acute appendicitis. Although parasites have been reported to cause appendicitis only by occluding the lumen with acute inflammation or by creating an inflammatory reaction, the role of parasites in the pathogenesis of appendicitis has not been clearly defined. ${ }^{2,3}$ Enterobius vermicularis (EV), Ascaris lumbricoides (AL), Schistosoma spp. and Taenia spp. are parasites that can cause acute appendicitis. Among these, the most widespread cause of acute appendicitis is $E V .4,5$

This study aimed to retrospectively evaluate patients with parasitic infestation who underwent appendectomy and were diagnosed with acute appendicitis.

\section{Materials and Method}

Electronic records of 7,344 patients who underwent appendectomy and who had acute appendicitis were analysed retrospectively. The analysis covered the period from January 2009 to January 2020. The study was performed in Ankara Training and Research Hospital General Surgery Clinic. For this type of study, informed consent is not required. Patients with parasitic infestation were evaluated in terms of age, gender, type of parasite and presence of inflammation.

\section{Results}

A total of 7,344 patients underwent appendectomy. Parasites were seen in 24 appendectomy specimens. Among those with parasitic infestation, 12 (50\%) were men and $12(50 \%)$ were women, with a mean age of 36.5 (range: 12-74) years. $E V$ was seen in $22(91.6 \%)$ patients, and $A L$ in 2 (8.4\%) patients. Acute inflammation was observed in 7 (31.8\%) of $E V$ cases but not in 15 (68.2\%). None of the AL cases had signs of acute inflammation (Table 1 ).

Table 1. Demographic parameters and histological findings of the patients

\begin{tabular}{|c|c|c|c|c|c|}
\hline No. of case & Age & Gender & Species of parasite & Acute inflammation & $\begin{array}{l}\text { Non-acute inflammation } \\
\text { (negatif laparotomi) }\end{array}$ \\
\hline 1 & 38 & Female & Enterobius vermicularis & No & Yes \\
\hline 2 & 31 & Female & Enterobius vermicularis & No & Yes \\
\hline 3 & 30 & Female & Enterobius vermicularis & Yes & No \\
\hline 4 & 23 & Female & Enterobius vermicularis & Yes & No \\
\hline 5 & 20 & Female & Enterobius vermicularis & No & Yes \\
\hline 6 & 19 & Female & Enterobius vermicularis & No & Yes \\
\hline 7 & 27 & Male & Enterobius vermicularis & Yes & No \\
\hline 8 & 64 & Male & Enterobius vermicularis & No & Yes \\
\hline 9 & 29 & Male & Enterobius vermicularis & No & Yes \\
\hline 10 & 34 & Female & Enterobius vermicularis & No & Yes \\
\hline 11 & 29 & Female & Enterobius vermicularis & No & Yes \\
\hline 12 & 27 & Male & Enterobius vermicularis & No & Yes \\
\hline 13 & 59 & Male & Enterobius vermicularis & Yes & No \\
\hline 14 & 27 & Female & Enterobius vermicularis & Yes & No \\
\hline 15 & 48 & Male & Ascaris & No & Yes \\
\hline 16 & 31 & Female & Enterobius vermicularis & No & Yes \\
\hline 17 & 54 & Male & Enterobius vermicularis & Yes & No \\
\hline 18 & 41 & Male & Enterobius vermicularis & Yes & No \\
\hline 19 & 31 & Female & Ascaris & No & Yes \\
\hline 20 & 36 & Male & Enterobius vermicularis & No & Yes \\
\hline 21 & 74 & Male & Enterobius vermicularis & No & Yes \\
\hline 22 & 50 & Female & Enterobius vermicularis & No & Yes \\
\hline 23 & 44 & Male & Enterobius vermicularis & No & Yes \\
\hline 24 & 12 & Male & Enterobius vermicularis & No & Yes \\
\hline
\end{tabular}




\section{Discussion}

Acute appendicitis is the most frequently observed condition that requires emergency surgery. ${ }^{6}$ Acute appendicitis most commonly occurs in the second and third decades of life and affects approximately $8.6 \%$ of men and $6.7 \%$ of women. ${ }^{7}$ Acute appendicitis can be caused by parasites, as they occlude the appendiceal lumen or lead to secondary inflammation. ${ }^{8}$ Acute inflammation findings may not be present in the histopathological examination of appendectomy specimens of parasitosis. ${ }^{9}$ Karatepe et al. ${ }^{8}$ showed that inflammation was not found in $25 \%$ of appendectomy specimens, while Ilhan et al. ${ }^{10}$ reported a rate of $52.7 \%$. In the present study, acute inflammation findings were not observed in $70.9 \%$ of appendectomy specimens with parasite invasion (Table 2).

$E V$ is the most frequent helminthic infection worldwide and is transmitted through faecal-oral transmission. ${ }^{11}$ In general, it is a common intestinal parasite in boys and girls and is more common in underdeveloped countries and regions with low socioeconomic status. ${ }^{12}$ Most people infected with EV are asymptomatic. Nevertheless, if symptoms develop, the most frequent one is anal pruritus. ${ }^{13}$ In addition, EV infections cause ileocolitis, enterocutaneous fistulas, urinary tract infections, mesenteric abscess, salpingitis and acute appendicitis. Mature forms of $E V$ are most often located in the ascending colon, cecum, appendix and terminal ileum. ${ }^{14,15}$ The relationship between EV and acute appendicitis was first discovered at the end of the $19^{\text {th }}$ century. ${ }^{16}$ Studies have established that EV caused pathological changes in the appendix, including lymphoid hyperplasia to acute phlegmatic appendicitis, gangrene appendicitis and peritonitis. ${ }^{4}$ In other studies, $E V$ is present in $0.35 \%-12.5 \%$ of specimens of patients undergoing appendectomy for acute appendicitis. ${ }^{12,13,14,15,16,17}$ Akkapulu and Abdullazade ${ }^{18}$ reported an $E V$ incidence rate of $0.62 \%$. In present study, the incidence of $E V$ was $0.32 \%$. Appendectomy is not an adequate treatment for cases with $E V$, since it does not eliminate the main cause in these patients and anti-helminthic treatment should also be administered. ${ }^{19}$ In the present study, antihelminthic treatment was given to patients with parasites.

\section{Study Limitations}

Ascariasis is one of the most common helminthic diseases and is most commonly caused by AL. It is most common in the jejunum and proximal ileum. AL can often mimic acute appendicitis clinically, but rarely causes acute appendicitis. In a rectrospective analysis of 324 appendectomy specimens, $A L$ was detected in only $3(0.9 \%)$ patients; none of whom had histopathological findings of acute appendicitis. ${ }^{20}$ Wani et al. ${ }^{21}$ showed that while histolopathological findings of acute appendicitis were not observed in $8(72.7 \%)$ of 11 patients with $A L$, acute appendicitis findings related to ascariasis were detected in $3(27.2 \%)$ patients. In the present study, $A L$ was seen in only two patients, neither of which had any histopathological findings associated with acute appendicitis.

\section{Conclusion}

In conclusion, parasites are among the possible aetiological causes of acute appendicitis. EV is the most common parasite in specimens of patients undergoing appendectomy. Negative laparotomy rates have been seen to be higher in the presence of parasitic invasion in the appendix. To reduce negative laparotomy rates and to minimise related side effects, patients with abdominal pain should be checked whether they have intestinal parasites, and this should be considered in the differential diagnosis. Patients with parasitic infestations should be given anti-helminthic therapy.

\section{Ethics}

Ethics Committee Approval: Ankara Training and Research Hospital Ethics Committee (date: 15.01.2021/no: 542).

Informed Consent: Retrospective study.

Peer-review: Externally peer reviewed.

Table 2. Data obtained from countries included in this study

\begin{tabular}{|c|c|c|c|c|c|}
\hline Author & Country & Total materials & Total, n (\%) & $\begin{array}{l}\text { Acute inflammation, } \\
\mathrm{n}(\%)\end{array}$ & $\begin{array}{l}\text { No acute } \\
\text { inflammation, } \mathrm{n}(\%)\end{array}$ \\
\hline Karatepe et al. ${ }^{8}$ & Turkey & 5,100 & $24(0.5)$ & $18(75)$ & $6(25)$ \\
\hline de Silva et al. ${ }^{4}$ & Brazil & 1,600 & $24(1.5)$ & $12(50)$ & $12(50)$ \\
\hline Zakaria et al. ${ }^{2}$ & Saudi Arabia & 1,600 & $88(5.5)$ & $54(61.4)$ & $34(38.6)$ \\
\hline Gialamas et al. ${ }^{14}$ & Greece & 1,085 & $7(0.64)$ & $1(14.3)$ & $6(85.7)$ \\
\hline Ilhan et al. ${ }^{10}$ & Turkey & 3,863 & $19(0.49)$ & $9(47.4)$ & $10(52.6)$ \\
\hline Current study & Turkey & 7,344 & $24(0.33)$ & $7(29.1)$ & $17(70.9)$ \\
\hline
\end{tabular}




\section{Authorship Contributions}

Surgical and Medical Practices: K.K., A.S., M.S., A.D., Concept: K.K., A.D., Design: K.K., M.S., Data Collection or Processing: K.K., M.S., Analysis or Interpretation: K.K., A.Ş., A.D., Literature Search: K.K., A.Ş., Writing: K.K., A.Ş.

Conflict of Interest: No conflict of interest was declared by the authors.

Financial Disclosure: The authors declared that this study received no financial support.

\section{References}

1. Becker K, Höfler H. Pathology of appendicitis. Chirurg 2002;73:777781.

2. Zakaria OM, Zakaria HM, Daoud MY, Wadaani HA, Buali WA, AlMohammed Al H, Mulhim SA, Zaki W. Parasitic infestation in pediatric and adolescent appendicitis: a local experience. Oman Med J 2013;28:92 96.

3. Ahmadi MH, Seifmanesh M. Taeniasis caused appendicitis without local tenderness: a rare case. Hospital Chronicles 2011;6:207-209.

4. de Silva DF, da Silva RJ, da Silva MG, Sartorelli AC, Rodrigues MAM. Parasitic infection of the appendix as a cause of acute appendicitis. Parasitol Res 2007;102:99-102.

5. Pasupati TM, Yothasamutr K, Wah MJ, Sherif SET, Palayan K. A study of parasitic infections in the luminal contents and tissue sections of appendix specimens. Tropical Biomedicine 2008;25:166-172.

6. Lally KP, Cox CS,Andrassy RJ (2004) The appendix. In: Townsend CM, Beauchamp RD, Evers BM, Mattox KL (eds) Sabiston textbook of surgery, 17th edn. WB Saunders, Philadelphia, pp 1381-1399.

7. Ahmadi MH, Seifmanesh M. Taeniasis caused appendicitis without local tenderness: a rare case. Hospital Chronicles 2011;6:207-209.

8. Karatepe O, Adas G, Tukenmez M, Battal M, Altiok M, Karahan S. Parasitic infestation as cause of acute appendicitis. G Chir 2009;30:426-428.

9. Çallı G, Özbilgin M, Yapar N, Sarıoğlu S, Özkoç S. Acute appendicitis and coinfection with enterobiasis and taeniasis: a case report. Turkiye Parazitol Derg 2014;38:58-60.
10. Ilhan E, Senlikci A, Kızanoglu H, Ustuner MA, Vardar E, Aykas A, Yeldan E, Yıdırım M. Do intestinal parasitic infestations in patients with clinically acute appendicitis increase the rate of negative laparotomy? Analysis of 3863 cases from Turkey. Prz Gastroenterol 2013;8:366-369.

11. Vleeschouwers W, Hofman P, Gillardin JP, Meert V, Van Slycke S. Appendicitis-like clinical image elicited by Enterobius vermicularis: case report and review of the literature. Acta Chir Belg. 2013;113:139-142.

12. Engin O,Calik S,Calik B, Yildirim M, Coskun G. Parasitic appendicitis from past to present in Turkey. Iranian Journal of Parasitology 2010;5:57-63.

13. Alemayehu H, Snyder CL, St Peter SD, Ostlie DJ. Incidence and outcomes of unexpected pathology findings after appendectomy. J Pediatr Surg. 2014:49:1390-1393.

14. Gialamas E, Papavramidis T, Michalopoulos, Karayannopoulou G, Cheva A, Vasilaki $O$ et al. Enterobius vermicularis: a rare cause of appendicitis. Turkiye Parazitol Derg 2012;36:37-40.

15. Sodergren MH, Jethwa P, Wilkinson S, Kerwat R. Presenting features of Enterobius vermicularis in the vermiform appendix. Scand J Gastroenterol 2009;44:457-461.

16. Stil GF. Oxyuriasis vermicularis in children. Br Med J 1899;1:898-900.

17. Isik B, Yilmaz M, Karadag N, Kahraman L, Sogutlu G, Yilmaz S, Kirimlioglu V. Appendiceal Enterobius vermicularis infestation in adults. Int Surg 2007:92:221-225

18. Akkapulu N, Abdullazade S. Is Enterobius vermicularis infestation associated with acut eappendicitis ? Eur J Trauma Emerg Surg. 2016;42:465-470

19. Nackley AC, Nackley JJ, Yeko TR, Gunasekaran S. Appendiceal enterobius vermicularis infestation associated with right-sided chronic pelvic pain. JSLS 2004;8:171-173

20. Chamisa I. A clinicopathological review of 324 appendices removed for acute appendicitis in Durban, South Africa: A retrospective analysis. Ann R Coll Surg Engl 2009;91:688-692.

21. Wani I, Maqbool M, Amin A, Shah F, Keema A, Singh J, Kitagawa M, Nazir M. Appendiceal ascariasis in children. Ann Saudi Med 2010;30:63-66. 